\title{
Cholangiocarcinoma Masquerading as IgG4-related Sclerosing Cholangitis
}

\author{
Sangyoung Yi', Dong hui Cho', Seungha Hwang', Kyunghwan Oh', Hyeon Jeong Kim', Jihun Kim², Myung-Hwan Kim \\ Departments of Internal Medicine and ${ }^{2}$ Pathology, Asan Medical Center, University of Ulsan College of Medicine, Seoul, Korea
}

IgG4-related sclerosing cholangitis (IgG4-SC) represents a rare but clinically challenging differential diagnosis in patients with biliary strictures which can be mistaken for cholangiocarcinoma. We present a case of a 73-year-old male presented with abdominal discomfort and weight loss. Biliary images showed long-segment luminal narrowing of extrahepatic bile duct associated with prominent enhanced wall thickening, but luminal patency was preserved. Pancreatic images revealed segmental irregular narrowing of main pancreatic duct without upstream duct dilatation. His liver function tests and CA19-9 level were normal. Putting all findings together, IgG4-SC associated with autoimmune pancreatitis was strongly suspected. However, endobiliary biopsy of extrahepatic bile duct revealed adenocarcinoma which was not resectable due to celiac axis involvement. Because there is an overlap in biliary imaging findings between IgG4-SC and cholangiocarcinoma, biopsy is essential for adequate differential diagnosis. We present a case of cholangiocarcinoma masquerading as IgG4-SC based on clinical and imaging findings.

Korean J Pancreas Biliary Tract 2016;21(3):168-173

Keywords: IgG4-related sclerosing cholangitis, Cholangiocarcinoma, Autoimmune pancreatitis

\author{
Received May 2,2016 \\ Revised May 25, 2016 \\ Accepted Jun. 7,2016
}

Corresponding author: Myung-Hwan Kim Division of Gastroenterology, Department of Internal Medicine, Asan Medical Center, University of Ulsan College of Medicine, 99 Olympic-ro 43gil, Sonpa-gu, Seoul 05505, Korea

Tel. +82-2-3010-3159 Fax. +82-2-476-0824

E-mail; mhkim@amc.seoul.kr

\section{서 론}

담관의 협착은 여러 가지 원인에 의해 유발되며 크게 악성 협착과 양성 협착으로 나눌 수 있다. 악성 담관 협착의 질환으
로는 원발성 담관암, 다른 부위 암의 담관전이가 있으며, 양성 담관 협착의 원인은 의인성 담관손상, 원발성 경화성 담관염 (primary sclerosing cholangitis), 세균 감염을 동반한 담관 결 석, 허혈성 담관염 등이 있다. 양성 담관 협착의 드문 원인 중 
하나인 IgG4 연관 경화성 담관염(immunoglobulin G4-related sclerosing cholangitis, IgG4-SC)은 면역 연관 전신 염증성 질 환인 IgG4 연관 질환이 담관을 침범한 경우로 담관 내강의 협 착과 담관벽 비후를 특징으로 하며, 특히 담관암과 감별이 매 우 중요하다. ${ }^{1,2}$

IgG4-SC는 자가면역성 췌장염(autoimmune pancreatitis, $\mathrm{AIP)}$ 을 비롯한 다른 $\mathrm{IgG} 4$ 연관 질환에서와 같이 스테로이드 에 매우 양호한 치료 반응을 보이는 것으로 알려져 있다. 이와 관련해서 IgG4-SC를 담관암으로 오인하여 불필요한 수술을 시행하였던 경우들이 드물지 않게 보고 되고 있으며, ${ }^{3}$ 반대로 담관암을 IgG4-SC로 오인하여 악성 종양의 근본적 치료인 수 술이 지연되는 것에 있어서도 주의가 필요하다. ${ }^{4}$

저자들은 여러 가지 임상 및 영상을 볼 때 IgG4-SC를 강하게 의심할 수 있는 상황에서 담관 생검상 담관암으로 확진되었던 증례를 경험하였기에 문헌 고찰과 함께 보고하는 바이다.

\section{증 례}

환자: 73세 남자

주소: 8 개월 전부터 발생한 상복부 불쾌감 및 6 개월간 $8 \mathrm{~kg}$ 의 체중감소

현병력: 상기 증상으로 연고지 의원에서 상부위장관내시경 검사를 시행받았고 그 결과 특이사항은 없었다. 그러나 증상이 지속되어 본원에 내원하였다.

과거병력: 특이사항은 없었다.

가족력 및 사회력: 특이 병력이 있는 가족은 없었고 음주는 하지 않았고 흡연력은 20갑년이었다.

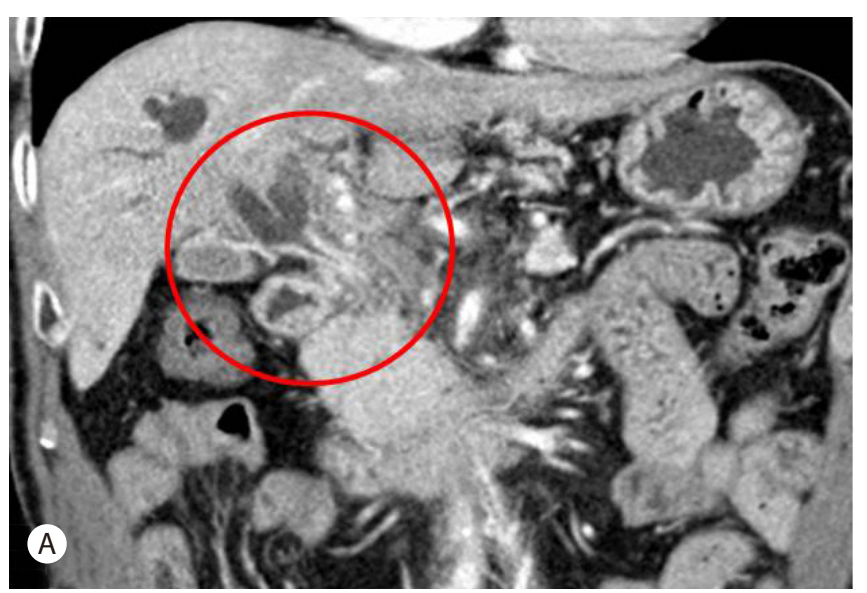

약물 복용력: 복용중인 약물은 없었다.

신체 검진: 내원 당시 활력 징후는 혈압 $106 / 65 \mathrm{mmHg}$, 맥박 분당 71 회, 호흡 분당 17 회, 체온 $36.7^{\circ} \mathrm{C}$ 로 정상이 었다. 의식은 명료하였고 만성 병색을 보였다. 공막의 황달 소견은 없었으며 복부의 압통이나 반발통은 없었 다. 장음은 정상이었다.

검사실 소견: 일반혈액검사에서 백혈구 $4,900 / \mathrm{mm}^{3}$, 혈색소 $12.0 \mathrm{~g} / \mathrm{dL}$, 혈소판 $199,000 / \mathrm{mm}^{3}$ 였다. 생화학 검사에서 아스파르테이트아미노전달효소 $24 \mathrm{IU} / \mathrm{L}$, 알라닌아미노 전달효소 $29 \mathrm{IU} / \mathrm{L}$, 알칼라인산분해효소 $86 \mathrm{IU} / \mathrm{L}$, 감마글 루타밀전달효소 $75 \mathrm{IU} / \mathrm{L}$, 총 빌리루빈 $0.6 \mathrm{mg} / \mathrm{dL}$ 였다. 아밀라아제는 $131 \mathrm{U} / \mathrm{L}$, 리파아제는 $18 \mathrm{U} / \mathrm{L}$ 였다. CA 19-9는 $2.5 \mathrm{U} / \mathrm{mL}$ 로 정상이었고, 혈청 면역글로불린 $\mathrm{G}$ 및 $\mathrm{G} 4$ 는 각각 $1,090 \mathrm{mg} / \mathrm{dL}(700-1,600 \mathrm{mg} / \mathrm{dL}), 42 \mathrm{mg} / \mathrm{dL}(<140$ $\mathrm{mg} / \mathrm{dL})$ 로 정상 범위 내에 있었다.

영상 검사 소견: 복부 CT상 간외담관벽이 현저하게 두꺼 워졌고 조영증강되었으며 근위부 담관은 확장되어 있었 다. 한편, 췌장 실질의 종대나 종괴 음영은 없었으나 복 강 동맥 주변으로 연부조직 침윤(soft-tissue infiltration) 이 관찰되었다(Fig. 1).

복부자기공명담췌관조영술(MRCP)상 원위부 총담관부

터 간문부까지 긴 협착이 보였으나 담관 내강의 개방성

은 유지되어 있었다. 내시경역행췌담관조영술(endoscopic retrograde cholangiopancreatography, ERCP)에 서 두부와 경부의 주췌관에 불규칙한 협착이 있었으나 상류 췌관의 확장은 동반되지 않았다(Fig. 2).

$\mathrm{ERCP}$ 및 조직검사 소견: $\mathrm{ERCP}$ 를 통해 경유두적으로 좁아

Fig. 1. Biliary dynamic Computed tomography findings. (A) Coronal image: Prominent wall thickening and enhancement of extrahepatic bile duct (circle) associated with proximal duct dilatation. (B) Cross-sectional image: Soft-tissue cuffing (circle) around celiac axis. 

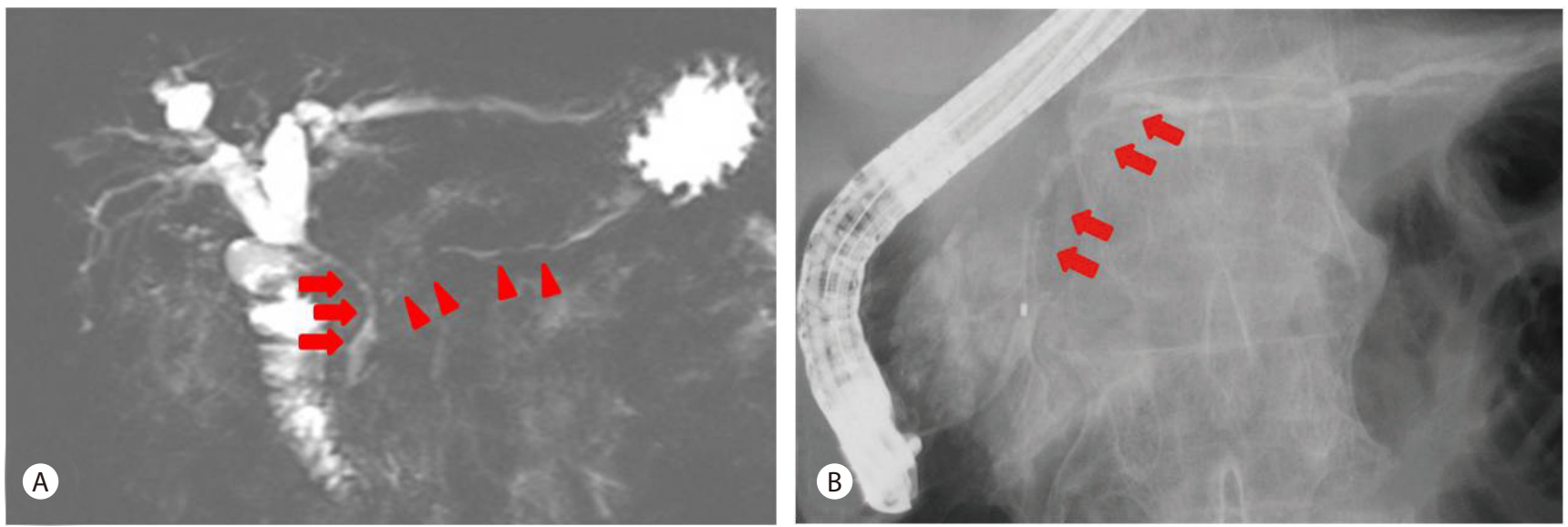

Fig. 2. (A) Initial Magnetic resonance cholangiopancreatography findings. Long-segment narrowing (arrows) of extrahepatic bile duct with proximal bile duct dilatation is noted. However, luminal patency in the narrowed segment is preserved. Main pancreatic duct is segmentally narrowed at the head and neck portion (arrow heads). (B) Endoscopic retrograde pancreatographic findings. Main pancreatic duct is segmentally narrowed at the head and neck portion (arrows) without upstream duct dilatation.
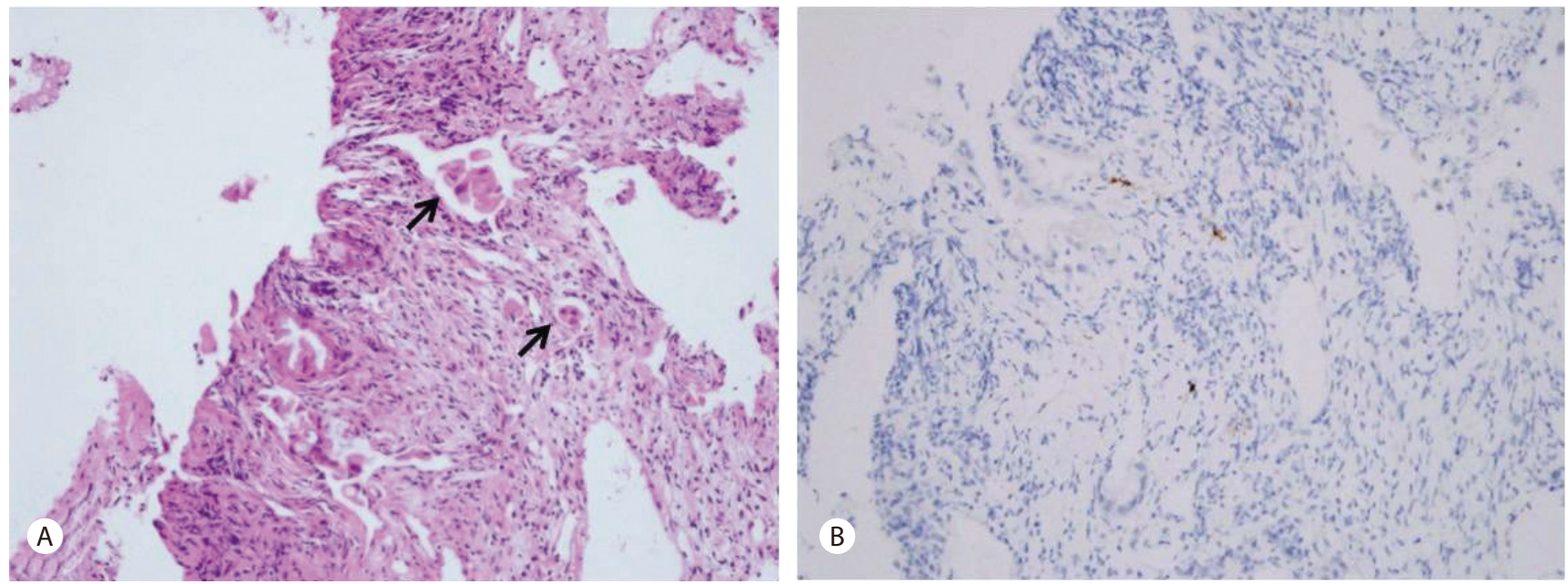

Fig. 3. Endobiliary biopsy findings. (A) A few clusters of infiltrating malignant cells (arrows) are inbedded in desmoplastic stroma (H\&E, $\times 100)$. (B) Only a few lgG4-positive cells are obserseved (lgG4, ×100).

진 담관을 대상으로 겸자 생검(forcep biopsy)을 시행하 였다. 담관 점막의 생검 결과 악성 세포(선암)가 보여 담 관암에 합당하였고, IgG4 양성 형질세포는 고배율 시야 에서 3 개 미만으로 관찰되었다(Fig. 3).

치료 및 경과: 담관암의 절제는 복강 동맥 침윤 소견으로 외과에서 수술시도 자체가 불가능하다고 판단하여 시행 되지 않았다. 이후 프레드니솔론을 매일 $30 \mathrm{mg}$ 씩 2주간 경구 복용시킨 후 $\mathrm{MRCP}$ 를 촬영하여 담관 및 췌관의 호 전 여부를 관찰하였으나 반응이 전혀 없었다(Fig. 4). 이 에 gemcitabine과 cisplatin을 이용한 항암치료를 시작하 였다.

\section{고 찰}

1995년 Yoshida 등이 처음으로 AIP의 개념을 제안한 이 후 많은 증례 보고들을 통해 이 질환이 다른 장기의 침범을 동반함이 알려졌고, 결국 현재는 $\operatorname{IgG} 4$ 의 증가를 특징으로 하 는 전신의 염증성 질환으로 이해되고 있다. IgG4-SC는 이러 한 IgG4 연관 질환의 담관 침범으로서 임상적, 영상학적으로 담관암과의 감별이 어려운 경우가 많아 특히 주의가 필요하 다. 영상 소견상 IgG4-SC와 담관암의 감별 포인트는 IgG4$\mathrm{SC}$ 에서는 협착 부위가 대칭성의 매끄러운 담관 표면, 긴 분 절의 협착에 비해 상대적으로 경한 근위부 담관의 확장, 담 관벽 비후가 현저한 것에 비해 담관 내강이 보존되는 점 
Table 1. Differentiation between IgG4-SC and cholangiocarcinoma based on biliary imaging

\begin{tabular}{ll}
\hline IgG4-SC & \multicolumn{1}{c}{ Cholangiocarcinoma } \\
\hline Symmetric(concentric) wall thickening & Asymmetric(eccentric) wall thickening \\
Smooth luminal surface & Irregular surface \\
Preserved luminal patency despite prominent wall thickening & Complete obliteration of bile duct lumen \\
Multifocal stricutres with intervening normal-looking duct & Single, localized \\
Relateively mild proximal duct dilatation despite a long stricture & Marked proximal duct dilatation \\
\hline
\end{tabular}

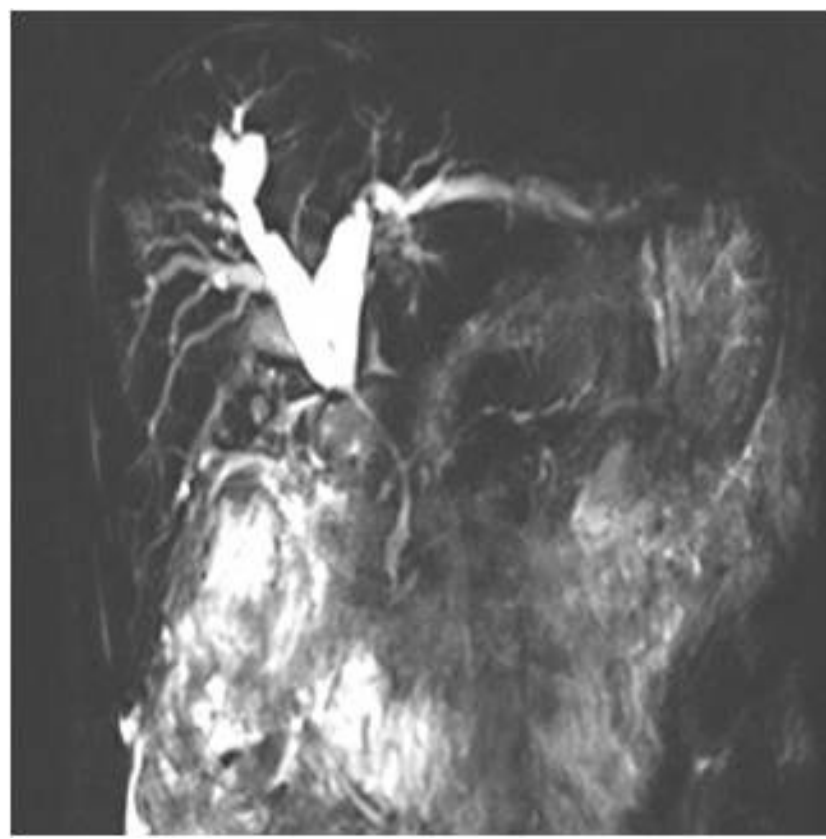

Fig. 4. Magnetic resonance cholangiopancreatography findings after a steroid trial. Pancreaticobiliary strictures did not improve at all after twoweek steroid trial.

(preserved luminal patency), 다발성 협착 등을 보일 수 있는 반면, 담관암은 담관 내강 협착이 비대칭성이며 내강 표면이 매끈하지 않고, 내강의 완전 폐쇄, 근위부 담관의 심한 확장 등을 특징으로 한다(Table 1). ${ }^{6}$ 한편 AIP의 과거력이 있거나, 현재 췌장에 $\mathrm{AIP}$ 를 시사하는 췌장 실질과 췌관의 변화가 있 는 경우, 그리고 침샘, 신장, 후복막에 IgG4 연관 질환의 증 거가 있는 경우에는 담관암보다는 IgG4-SC를 더 시사한다 고 할 수 있다. ${ }^{1}$

본 증례의 환자는 간문부에서 원위부 총담관에 이르는 긴 분절의 담관 협착과 심한 담관벽의 비후 및 담관벽의 조영증 강, 복강 동맥 주변으로의 연부조직 침윤이 보였고 이러한 검사 소견들은 질병의 발생 빈도로 보면 IgG4-SC보다는 담 관암을 우선적으로 고려할 수 있는 소견이었다. 그러나 황달 이 없고 악성 담관 협착시 흔히 증가하는 혈중 아스파르테이
트아미노전달효소와 알라닌아미노전달효소가 완전 정상이 었다는 점이 담관암과 맞지 않았다. 또한 $\mathrm{MRCP}$ 에서 간외담 관이 긴 분절에 걸쳐 심하게 좁아져 있으나 담관 내강의 개 방성이 유지되어 있었고 혈중 종양 표지자(CA 19-9)도 증가 되어 있지 않았다. 추가적으로 음주력이 없음에도 ERCP에 서 주췌관의 불규칙적인 분절성 협착이 관찰되었으나 상류 췌관 확장이나 췌장 실질 위축은 관찰되지 않아서 일반적인 만성 췌장염에도 맞지 않았다. 위에서 언급한 소견들을 종합 할 때 AIP를 동반한 IgG4-SC가 강력히 의심되었다.

하지만 $\mathrm{ERCP}$ 를 통한 담관내 생검에서 $\mathrm{IgG} 4$ 양성 형질세 포가 고배율 시야에서 3 개 미만으로 관찰되었고 악성 세포 (선암)가 보여 담관암으로 확진 되었다. 최근에 기저에 IgG4-SC가 있는 상태에서 발생한 담관암이 의심되는 증례 들이 보고 되고 있으며, ${ }^{7,8}$ 본 증례도 그러한 가능성을 완전히 배제하기는 어려울 것으로 보인다. 하지만 환자가 특별한 과 거 병력이 없고 조직 생검에서 lymphoplasma cell infiltration이 없었으며, 스테로이드 투약 후에도 췌관 협착이 호전 되지 않았던 점은 기저에 IgG4-SC 혹은 AIP가 있었을 가능 성이 낮음을 시사한다. 한편, 생검을 통해 IgG4-SC를 진단하 기가 쉽지 않은데 이는 경유두적 담관 생검이 IgG4-SC의 특 징적 조직 소견을 보여주기에는 충분히 깊게 시행되기 어렵 기 때문이다. ${ }^{9}$ 또한 $\operatorname{IgG} 4$ 면역 염색 양성 반응은 담관암에서 도 드물지 않게 나올 수 있다. ${ }^{4,10}$ 저자들의 이전 경험에 따르 면 IgG4-SC 역시 AIP와 마찬가지로 스테로이드를 2주간 투 여하면 담관 협착이 현저히 호전되어 스테로이드에 전혀 반 응이 없는 담관암과 감별할 수 있었다. 따라서 조직검사로도 IgG4-SC와 담관암의 감별이 어려울 때에는 2주간 스테로이 드(프레드니솔론 매일 $30 \mathrm{mg}$ 경구 복용)를 투여한 후 영상 검사를 통해 담관 협착과 담관벽 비후 소견의 호전 여부를 확인하는 것이 감별진단에 도움이 될 수 있다.

본 증례에서 보였던 췌관의 불규칙한 협착은 주췌관의 확 장, 췌장 실질 위축 및 췌석회화 없이 불규칙한 분절성 협착 
을 보이고 있어 일반적인 만성 췌장염에 맞지 않았고 음주력 이나 급성 췌장염의 과거력도 없었다. 이런 형태의 췌관 이 상이 보일 경우 자가 면역 췌장염에 의한 변화를 의심해 볼 수 있겠으나, 본 증례에서는 스테로이드 투약에 반응이 없어 자가 면역 췌장염과 관련된 췌관의 이상은 아닐 것으로 판단 하였으며, 원인이 불명확한 만성 췌장염에 의한 변화였으리 라 추정된다.

본 증례를 통해서 IgG4-SC와 담관암의 감별에 있어서 문 헌상 알려진 영상 소견이나 혈액 검사상의 감별점은 두 질환 에서 중복되어 나타날 수 있어 주의가 필요함을 알 수 있었 다. 한 보고에 의하면, 담관에 협착이 있고 췌장은 정상 소견 이었던 IgG4-SC 의심 증례에서, 스테로이드를 투여하였으 나 반응이 없었고, 최종적으로는 담관암으로 진단되었던 증 례들이 있었다. ${ }^{11}$ 본 증례에서는 췌관에 이상 소견도 동반되 어 있어 영상 소견으로는 더욱 감별이 어려웠던 것으로 보인 다. 또한 이 증례는 IgG4-SC가 강하게 의심되더라도 반드시 조직 진단을 통해 악성 질환을 배제하기 위한 노력을 게을리 하지 말아야 함을 시사한다. 최근 IgG4-SC에 대한 인식이 확 대되면서 환자들이 불필요한 수술을 피할 수 있게 된 것은 매우 의미 있는 변화라고 생각되나, 자칫 악성 질환의 배제 를 위한 깊이 있는 진단 과정을 거치지 않고 스테로이드 투 여를 지속하는 우를 범하지 않도록 주의가 필요하겠다.

본 증례의 환자는 외과적 절제가 곤란한 상태였고 문헌에 보면 드물게 생검 결과가 위양성으로(담관암이 아님에도 불 구하고 담관암으로 생검 결과가 잘못 해석됨) 나오는 경우가 있으며, ${ }^{12}$ 스테로이드 투여로 인한 2주간의 항암제 투여 연기 가 전체적인 담관암의 예후나 경과에 영향을 끼치지 않는다 고 판단하여 진단 목적으로 스테로이드를 투여하였다. 그러 나 2주간의 고용량 스테로이드 투여 후 촬영한 $\mathrm{MRCP}$ 에서 담도와 췌관의 협착이 전혀 호전되지 않아 IgG4-SC나 AIP를 배제할 수 있었다.

\section{요 약}

IgG4-SC는 type $1 \mathrm{AIP}$ 의 가장 흔한 췌장 외 발현으로 type $1 \mathrm{AIP}$ 환자의 약 70\%에서 발생하는 것으로 보고되었고 드물 게 단독으로 발생하기도 한다. IgG4-SC의 진단은 임상적으 로 매우 중요한데, 이는 영상 소견상 담관암과의 감별이 어 렵기 때문이다. IgG4-SC의 경우, 스테로이드 투여로 회복될 수 있다는 점에서 그 의의가 크다.
이번 증례 보고에서 저자들은 증상이 경미하고 영상 검사 에서 IgG4-SC를 충분히 의심할만한 환자에서 조직검사 및 스테로이드 투여를 통해 담관암으로 확진된 증례를 경험하 였기에 확진을 위한 생검의 중요성을 다시 강조하면서 문헌 고찰과 함께 보고하는 바이다.

국문 색인: $\operatorname{lgG} 4$ 연관경화성 담관염, 담관암, 자가면역성 췌 장염

\section{REFERENCES}

1. Ghazale A, Chari ST, Zhang L, et al. Immunoglobulin G4-associated cholangitis: clinical profile and response to therapy. Gastroenterology 2008; 134:706-715

2. Fujita T, Kojima M, Gotohda N, et al. Incidence, clinical presentation and pathological features of benign sclerosing cholangitis of unknown origin masquerading as biliary carcinoma. J Hepatobiliary Pancreat Sci 2010;17:139-146

3. Erdogan D, Kloek JJ, ten Kate FJ, et al. Immunoglobulin G4-related sclerosing cholangitis in patients resected for presumed malignant bile duct strictures. Br J Surg 2008;95:727-734.

4. Oseini AM, Chaiteerakij R, Shire AM, et al. Utility of serum immunoglobulin G4 in distinguishing immunoglobulin G4-associated cholangitis from cholangiocarcinoma. Hepatology 2011;54:940-948.

5. Yoshida K, Toki F, Takeuchi T, Watanabe S, Shiratori K, Hayashi N. Chronic pancreatitis caused by an autoimmune abnormality. Proposal of the concept of autoimmune pancreatitis. Dig Dis Sci 1995;40:15611568.

6. Oh HC, Kim MH, Lee KT, et al. Clinical clues to suspicion of IgG4associated sclerosing cholangitis disguised as primary sclerosing cholangitis or hilar cholangiocarcinoma. J Gastroenterol Hepatol 2010;25:1831-1837.

7. Straub BK, Esposito I, Gotthardt D, et al. IgG4-associated cholangitis with cholangiocarcinoma. Virchows Arch 2011;458:761-765.

8. Zhang YA, Shen XZ, Zhu JM, Liu TT. Extensive metastatic cholangiocarcinoma associated with IgG4-related sclerosing cholangitis misdiagnosed as Isolated IgG4-related sclerosing cholangitis: a case report and literature review. Medicine (Baltimore) 2015;94:e2052.

9. Rösch T, Hofrichter K, Frimberger $E$, et al. ERCP or EUS for tissue diagnosis of biliary strictures? A prospective comparative study. Gastrointest Endosc 2004:60:390-396.

10. Kimura Y, Harada K, Nakanuma Y. Pathologic significance of immunoglobulin G4-positive plasma cells in extrahepatic cholangiocarcinoma. Hum Pathol 2012;43:2149-2156.

11. Lytras D, Kalaitzakis E, Webster GJ, et al. Cholangiocarcinoma or 
IgG4-associated cholangitis:how feasible it is to avoid unnecessary surgical interventions? Ann Surg 2012;256:1059-1067.

12. Layfield LJ, Cramer H. Primary sclerosing cholangitis as a cause of false positive bile duct brushing cytology: report of two cases. Diagn Cytopathol 2005;32:119-124. 